\title{
STRUCTURE OF A QUESTIONNAIRE ON CHILDREN'S ATTITUDES TOWARDS INCLUSIVE PHYSICAL EDUCATION (CAIPE-CZ)
}

\author{
Martin Kudláček, Ondřej Ješina, Julie Wittmanová
}

Faculty of Physical Culture, Palacký University, Olomouc, Czech Republic

Submitted in October, 2011

BACKGROUND: The process of educating children with and without disabilities together has had many titles in the past, starting with mainstreaming, changing into integration and finally arriving at the current title of inclusion. While inclusion has become widespread, studies aiming to help us understand this phenomenon and variables that influence it have been limited mainly to the study of inclusion as a process and attitudes of teachers towards inclusive physical education. In order to study inclusion we also need to have questionnaires to measure the beliefs of children without disabilities.

OBJECTIVE: The purpose of this study was to translate and modify the CAIPE-R instrument, to describe the structure of its components and to compare the structure of CAIPE's Czech version (CAIPE-CZ) to the original instrument.

METHODS: The original questionnaire, CAIPE-R (Block, 1995), was modified and translated using a standard back translation procedure. Data were collected from 140 girls (mean age 13.12 years, $\mathrm{SD}=1.61$ ) and 146 boys (mean age 13.26 years, $\mathrm{SD}=1.48$ ) and analyzed using SPSS-PC 19.0 software.

RESULTS: The results of principal component factor analysis with Varimax rotation have proven the two component structure of the CAIPE-CZ questionnaire. The first four items are loaded in one factor which was titled as "General beliefs about inclusion in physical education". In contrast with the original CAIPE-R questionnaire, the fifth and sixth items are loaded to the second component together with 4 other items. This component was titled "Beliefs about actual behavior".

CONCLUSION: CAIPE-CZ was translated using a standardized procedure and shows a high internal consistency and is also sensitive to detecting differences between groups of children with personal experiences with students with disabilities and those without such experiences. Thus CAIPE-CZ is ready to use for future studies about the attitudes of children towards inclusive physical education.

Keywords: Adapted physical activity, adapted physical education, disability, special education.

\section{INTRODUCTION}

International studies (Kudláček, Válková, Sherrill, Myers, \& French, 2002; Lienert, Sherrill, \& Myers, 2001; Meegan \& MacPhail, 2006 or Smith, 2004) tell us that with a growing number of students with disabilities being included in general education, more and more physical education teachers face the reality of teaching these students together with students without disabilities. In most cases teachers cannot make decisions as to whether to include or not a student with a disability in their class, they can only decide to which extent to include this student (Lienert et al., 2001). The process of educating children with and without disabilities together has had many titles in the past starting with mainstreaming, changing into integration and finally arriving to the current title of INCLUSION. This term is almost universally accepted in English terminology, however, in some countries different names (e.g. integration) are still used preferably. While inclusion has become a widespread phenomenon (Block, 2007; Sherrill, 2004), stud- ies aiming to help us understand this phenomenon and variables that influence it have been limited. A recent review of studies on inclusion from 1995 to 2005 by Block and Obrusníková (2007) distinguished six focus areas of the state of knowledge - (a) support; (b) effects on peers without disabilities; (c) attitudes and intentions of children without disabilities; (d) social interactions; (e) ALT-PE of students with disabilities; and (f) training and attitudes of GPE teachers. In this article we are interested in one of the key areas titled - attitudes and intentions of children without disabilities toward inclusive physical education.

In literature focused on adapted physical activity attitudes toward participation in physical activity and attitudes toward inclusion a very important part is played by what is considered to be one of the key competencies of physical educators (Hutzler, 2003; Sherrill, 2004) and that is this important variable influencing the behavior and interaction of peers without disabilities in inclusive physical education. Founders of social psychology Krech and Crutchfield (1948, p. 152) 
defined attitudes as: "An enduring organization of motivational, emotional, perceptual, and cognitive processes with respect to some aspect of the individual world." Belief was defined by Krech and Crutchfield (1948) as an enduring organization of perception and cognition. They also used the term belief as a representation of (a) knowledge, (b) opinions, and (c) faith. Opinion was said to be a "...special kind of belief, which may persist in a stable way for the individual over a period of time" (Krech \& Crutchfield, 1948, p. 158). In a later phase of attitudinal inquiry, a multicomponent view of attitudes was adopted almost universally. Attitudes were conceptualized as (a) a person's beliefs about an object, (b) a person's feelings toward the object, and (c) action tendencies with respect to the object (Ajzen \& Fishbein, 1980, p. 19). Attitudinal research in adapted physical activity has focused on the past twenty years in attitudes of physical education teachers starting with research utilizing the theory of planned behavior by Terry Rizzo (1984) followed by the in line of research using the theory of reasoned action (Downs \& Williams, 1994; Rizzo \& Kirkendall, 1995; Rizzo \& Vispoel, 1991; Rizzo \& Wright, 1988). In a Czech context, attitudes of physical educators towards inclusion were studied by Kudláček et al. (2002) and recently by Kudláček (2007). Participation in inclusive physical education in the Czech lands was also studied by Halamičková and Válková (2003).

Studies of students in relation to inclusive physical education focus predominantly on experiences of students with special educational needs (Goodwin, 2000; Goodwin \& Watkinson, 2001). Block and Vogler (1994) and Obrusníková, Válková, and Block (2003) focused on the impact of inclusion on students without disabilities. In order to study the impact of inclusive physical education on students' attitudes we need a valid and reliable instrument. Such an attitudinal questionnaire entitled CAIPE (Children's Attitude toward Inclusive Physical Education) was developed and validated by American scholar Martin Block (1995). The purpose of this study was to translate the CAIPE-R instrument, to describe the structure of its components, compare the structure of CAIPE's Czech version to the original instrument and to compare attitudes of students with and without personal experience with persons with disabilities.

\section{METHODS}

\section{Questionnaire CAIPE}

According to Block (1995), the CAIPE-R is generalizable to more than one disability label and appears to be a valid and reliable instrument measuring attitudes of children without disabilities towards including children with disabilities in physical education. The original ver- sion of the CAIPE-R, a validated attitude survey with an internal reliability coefficient of 0.37 , a test-retest reliability coefficient of 0.78 for the general attitude scale, and a 0.66 internal and 0.56 test-retest reliability coefficients for the sport-specific scale, is designed to measure children's attitudes toward having students with disabilities in their regular physical education class (Block, 1995). The questionnaire consists of basic questions, where we were informed about each pupil (name, gender, age, class and place of residence). Further the questionnaire informs us if in his/her family, class or somebody from among his/her friends has the disability. Other information is if the pupil had the contact with children with disability in physical education or in some other subject. Other questions said to us how it is with competitiveness: very competitive (I like to win, and I get very upset if I lose), kind of competitive (I like to win, but it is $\mathrm{OK}$ if I lose sometimes), not competitive (It really doesn't matter to me if I win or lose; I just play for fun). The next questions were about a boy named Peter, who has a disability and can go to physical education. Before the children enter their answers into the questionnaire, they were read to about Peter using the following text: "Peter is the same age you are. However, he cannot walk, so he uses a wheelchair to get around. Peter likes playing the same games you do, but he does not do very well in the games. Even though he can push his wheelchair, he is slower than you and tires easily. He can throw a ball, but not very far. He can catch balls that are tossed straight to him, and he can hit a baseball off a tee, but he cannot shoot a basketball high enough to make a basket. Because his legs do not work, he cannot kick a ball.”

\section{Modification and translation of the instrument}

CAIPE-R was initially modified by a group of European experts in the project Paralympic School Day as CAIPE-R uses baseball related items, a sport not widely used in European physical education. Based on personal communication with the author of a questionnaire modification using basketball, a new version was developed by a group of four experts, who were university teachers holding PhDs. in adapted physical activity from the Czech Republic, Belgium, Latvia and Greece. The modified CAIPE-R was translated from English to Czech using standard back translation procedures suggested by Banville, Desrosiers, and Genet-Volet (2000).

"The four translators were bilingual university academic staff in kinesiology. First, two translators (A and B) translated the original English version of the CAIPE-R questionnaire into the Czech language. The following instruction was given to the translators: "The literal translation was neither essential nor desired. Please look for the meaning of the statement rather than the word for word translation.” When translators A and B 
finished, they compared their versions and engaged in a discussion to arrive at agreement. The Czech version of the CAIPE questionnaire was then given to two other bilingual persons (C and D) who translated the instrument back to English. Translators $C$ and D did not know the original version. If the meaning of the retranslated statement was the same as the original, the translated statement was kept. If the meaning was different, the committee consisted of a principal investigator and translator A revised the translated version so that, when retranslated into English, its meaning was identical to that of the original version" (Kudláček et al., 2002, p. 285).

\section{Participants}

Data were collected from 140 girls (mean age 13.12 years, $\mathrm{SD}=1.61$ ) and 146 boys (mean age 13.26 years, $S D=1.48)$. Fifty six students had previous experiences with students with disability in their physical education class and 230 students did not have such experience. Students were selected from a school which signed up for the program Paralympic School Day. Data for this article were collected prior to the program Paralympic School Day.

\section{Statistical analysis}

In order to describe the structure of the translated questionnaire we have used the factor analysis test using SPSS PC 19.0 principal component extraction with varimax rotation. For comparison of the attitudes of students with and without personal experience with persons with disabilities, an independent sample t-test with a set value of statistical significance below 0.05 in SPSS PC 19.0 was utilized.

\section{RESULTS}

Following the structure of CAIPE-R we have compared students who had personal experience with students with disabilities with those who did not have such personal experience using the t-test in SPSS-PC 19.0. The overall results were not significantly different, but the analysis of separate items favored students with personal experience (TABLE 1) with two items showing significant differences.

CAIPE-CZ shows high internal consistency analyzed by means of Cronbach alpha $(\alpha=0.84)$. Factor analysis was done in agreement with the attitudinal studies of Block (1995) and Kudláček (2007) using principal component factor analysis with Varimax rotation. The results prove the two component structure of the CAIPE-CZ questionnaire (TABLE 2).

This structure is similar to the original CAIPE-R scale by Block (1995). However items were structured in a slightly different way. Item no. 10 (in basketball it would be good if nobody could steal the ball from Peter while passing) did not load and thus we suggest leaving this item out of the CAIPE-CZ questionnaire. The first four items loaded in one factor which was entitled as "General beliefs about inclusion in physical education". In contrast to the original CAIPE-R questionnaire, the fifth and sixth items loaded to the second component together with the other 4 items. This component was entitled "Beliefs about actual behavior".

\section{DISCUSSION}

The purpose of this study was to translate the CAIPE-R instrument, to describe the structure of its components, compare the structure of CAIPE's Czech version to the original instrument and compare attitudes of students with and without personal experience with persons with disabilities. Translation was done using a procedure outlined by Banville et al. (2000) and the CAIPE-CZ shows a high internal consistency comparable to the original CAIPE-R (Block, 1995). In contrast to CAIPE-R components, CAIPE-CZ consists of slightly different items, which were named - (a) general beliefs about inclusion in physical education and (b) beliefs about actual behavior while Block (1995) divided CAIPE-R into two components - (a) beliefs about inclusion and (b) beliefs about sport specific rule modifications. The study shows also differences between groups of students with and without experience with children with physical disabilities. The availability of a questionnaire focused on attitudes of children without disabilities is a foundation for further studies aimed at specific intervention programs or pre-conditions of inclusive physical education. The questionnaire CAIPE-CZ has been already utilized for studies of the impact of the Paralympic School Day in the Czech Republic on attitudes towards inclusion (Xafopoulos, Kudláček, \& Evaggelinou, 2009; Yang, Kudláček, \& Ješina, 2010).

\section{CONCLUSIONS}

CAIPE-CZ was translated using a standardized procedure and shows a high internal consistency and is also sensitive to detecting differences between groups of children with personal experience with students with disabilities and those without such experience. Thus CAIPE-CZ is ready to use for future studies about the attitudes of children towards inclusive physical education. A limitation of this study of the instrument CAIPE-CZ and the original instrument CAIPE-R is in the description of the student with physical disabilities using a vignette. On one hand some students without disabilities might have problems imagining the student with a physi- 
TABLE1

Descriptive statistics on CAIPE-CZ items of students with and without personal experience with peers with disability

\begin{tabular}{|l|c|c|c|c|}
\hline & With experience & \multicolumn{2}{c|}{ Without experience } \\
\hline & M & SD & M & SD \\
\hline 1. It would be OK having Peter come to my P. E. class. & 3.20 & 0.77 & 2.83 & 0.83 \\
\hline 2. Because Peter cannot play sports very well, he would slow down the game for everyone. & 2.61 & 1.07 & 2.54 & 0.97 \\
\hline $\begin{array}{l}\text { 3. If we were playing a team sport such as basketball, it would be OK having Peter on } \\
\text { my team. }\end{array}$ & 2.73 & 0.96 & 2.50 & 0.94 \\
\hline 4. P. E. would be fun if Peter was in my P. E. class. & 3.30 & 0.87 & 2.96 & 0.93 \\
\hline 5. If Peter were in my P. E. class, I would talk to him and be his friend.* & 3.66 & 0.58 & 3.50 & 0.67 \\
\hline 6. If Peter were in my P. E. class, I would like to help him practice and play the games. & 3.54 & 0.81 & 3.49 & 0.76 \\
\hline 7. In basketball would I be willing to make a pass to Peter? & 3.62 & 0.77 & 3.58 & 0.74 \\
\hline 8. In basketball I would allow Peter to shoot at a lower basket.** & 3.80 & 0.62 & 3.62 & 0.78 \\
\hline 9. Peter could stay in the keyhole longer (five seconds instead of three). & 3.66 & 0.69 & 3.58 & 0.75 \\
\hline 10. In basketball it would be good if nobody could steal the ball from Peter while passing. & 3.38 & 0.93 & 2.83 & 1.06 \\
\hline 11. I would be willing to help Peter to score the basket. & 3.73 & 0.73 & 3.63 & 0.67 \\
\hline
\end{tabular}

Legend: $\mathrm{M}=$ mean; $\mathrm{SD}=$ standard deviation; ${ }^{*} \mathrm{p}<0.05 ;{ }^{* *} \mathrm{p}<0.01$ in t-test

\section{TABLE 2}

Component loadings, eigenvalues and percentages of variance using principal component extraction with varimax rotation for total composite scores

\begin{tabular}{lcl}
\hline Item \# & Varimax components \\
\hline Beliefs about actual behavior & & \\
5 & 0.55 & \\
6 & 0.64 & \\
7 & 0.73 & \\
8 & 0.81 & \\
9 & 0.67 & 0.69 \\
1 & 0.75 & 0.55 \\
\hline General beliefs about inclusion in physical education & 0.82 \\
1 & & 0.77 \\
2 & & 1.36 \\
3 & & 12.40 \\
4 & 4.47 & \\
\hline Eigen value & 40.65 & \\
Percent variance & & \\
\hline
\end{tabular}

Legend: Item \# means the number of the statement on the questionnaire. The order of items is available in TABLE 1.

cal disability and at the same time the vignette focuses on the limitations of the student with a physical disability in participation and thus can negatively influence their responses. In future studies of the attitudes of children without disabilities in inclusive physical education, we suggest translating and utilizing the Adjective checklist by Siperstein (1980) and the theoretically sound TPB scale measuring children's intentions to play with a hypothetical peer with a disability in inclusive physical education recently developed by Obrusníková, Block, and Dillon (2010).

\section{REFERENCES}

Ajzen, I., \& Fishbein, M. (1980). Understanding attitudes and predicting behavior. Englewood Cliffs, $\mathrm{NJ}$ : Prentice-Hall.

Banville, D., Desrosiers, P., \& Genet-Volet, Y. (2000). Translating questionnaires and inventories using a cross cultural translation technique. Journal of Teaching in Physical Education, 19(3), 374-387.

Block, M. (1995). Development and validation of children's attitudes toward integrated physical educa- 
tion-revised (CAIPE-R) inventory. Adapted Physical Activity Quarterly, 12(1), 60-77.

Block, M. E. (2007). A teachers' guide to including students with disabilities in general physical education (3rd ed.). Baltimore: Paul H. Brookes.

Block, M. E, \& Obrusníková, I. (2007). Inclusion in physical education: A review of the literature from 1995-2005. Adapted Physical Activity Quarterly, 24(2), 103-124.

Block, M. E, \& Vogler, E. W. (1994). Inclusion in regular physical education: The research base. Journal of Physical Education, Recreation and Dance, 65(1), 40-44.

Downs, P., \& Williams, T. (1994). Student attitudes toward integration of people with disabilities in activity settings: A European comparison. Adapted Physical Activity Quarterly, 11(1), 32-43.

Goodwin, D. L. (2001). Meaning of help in PE: Perceptions of students with physical disabilities. Adapted Physical Activity Quarterly, 18(3), 189-303.

Goodwin, D. L., \& Watkinson, E. J. (2000). Inclusive physical education from the perspective of students with physical disabilities. Adapted Physical Activity Quarterly, 17(2), 144-160.

Halamičková, K., \& Válková, H. (2003). Didactic categories in inclusive physical education lessons at the secondary school level: A case study. Acta Universitatis Palackiana Olomucensis. Gymnica, 29(2), 49-56.

Hutzler, Y. (2003). Attitudes toward the participation of individuals with disabilities in physical activity: A review. Quest, 55(4), 347-373.

Krech, D., \& Crutchfield, R. S. (1948). Theory and problems in social psychology. New York: McGraw-Hill.

Kudláček, M. (2007). Components of attitudes toward inclusion of students with physical disabilities in physical education in the revised "ATIPDPE-R" instrument/scale for prospective Czech educators. Acta Universitatis Palackianae Olomucensis. Gymnica, 37(1), 13-18.

Kudláček, M., Válková, H., Sherrill, C., Myers, B., \& French, R. (2002). An inclusion instrument based on planned behavior theory for prospective Czech physical educators. Adapted Physical Activity Quarterly, 19(3), 280-299.

Lienert, C., Sherrill, C., \& Myers, B. (2001). Physical educators' concerns about integrating children with disabilities: A cross cultural comparison. Adapted Physical Activity Quarterly, 18(1), 1-17.

Meegean, S., \& MacPhail, A. (2006). Irish physical educators' attitude toward teaching students with special educational needs. European Physical Education Review, 12(1), 75-97.

Obrusníková, I., Block, M., \& Dillon, S. (2010). Children's beliefs toward cooperative playing with peers with disabilities in physical education. Adapted Physical Activity Quarterly, 27(2), 127-142.
Obrusníková, I., Válková, H., \& Block, M. E. (2003). Impact of inclusion in general physical education on students without disabilities. Adapted Physical Activity Quarterly, 20(3), 230-245.

Rizzo, T. L. (1984). Attitudes of physical educators toward teaching handicapped pupils. Adapted Physical Activity Quarterly, 1(4), 267-274.

Rizzo, T. L., \& Kirkendall, D. R. (1995). Teaching students with mild disabilities: What affects attitudes of future physical educators? Adapted Physical Activity Quarterly, 12(3), 205-216.

Rizzo, T. L., \& Vispoel, W. P. (1991). Physical educators' attributes and attitudes toward teaching students with handicaps. Adapted Physical Activity Quarterly, 8(1), 4-11.

Rizzo, T. L., \& Wright, R. G. (1988). Physical educators' attitudes toward teaching students with handicaps. Mental Retardation, 26(5), 307-309.

Sherrill, C. (2004). Adapted physical activity: Crossdisciplinary and lifespan (6th ed.). Boston, MA: WCB/ Mc Graw-Hill.

Siperstein, G. N. (1980). Instruments for measuring children's attitudes toward the handicapped. Unpublished manuscript, University of Massachusetts, Boston.

Smith, A. (2004). The inclusion of pupils with special educational needs in secondary school physical education. Physical Education and Sport Pedagogy, 9(1), 37-53.

Xafopoulos, G., Kudláček, M., \& Evaggelinou, C. (2009). The effect of the intervention program "Paralympic School Day" on attitudes of children attending international school towards inclusion of students with disabilities. Acta Universitatis Palackianae Olomucensis. Gymnica, 39(4), 63-71.

Yang, L., Kudláček, M., \& Ješina, O. (2010). The influence of Paralympic School Day on children's attitudes towards people with disabilities, Acta Universitatis Palackianae Olomucensis. Gymnica, 40(2), 63-69.

\section{STRUKTURA ČESKÉHO PŘEKLADU DOTAZNÍKU „CHILDREN'S ATTITUDES TOWARD INCLUSIVE PHYSICAL EDUCATION“ (CAIPE-CZ) \\ (Souhrn anglického textu)}

VÝCHODISKA: Společné vzdělávání žáků se zdravotním postižením a žáků intaktních mělo v minulosti vice názvů. $\mathrm{V}$ češtině v současnosti převládá termín integrace a v angličtině termín inkluze (inclusion). Většina výzkumu se prozatím orientovala na postoje učitelů tělesné výchovy, ale úspěšná integrace je podmíněná porozuměním také postojům intaktních žáků. $Z$ tohoto důvodu je třeba kvalitních a standardizovaných metodologických nástrojů. 
CíLE: Cílem této studie je přeložit modifikovaný dotazník CAIPE-R, popsat jeho strukturu a porovnat strukturu českého překladu s originálním dotazníkem.

METODIKA: Dotazník CAIPE-R (Block, 1995) byl modifikován a přeložen s využitím standardní procedury zpětného překladu. Výzkumný vzorek tvořilo 140 dívek (průměrný věk $=13,12$ roků) a 146 chlapců (průměrný věk $=13,26$ roků). Analýza byla provedena s využitím softwaru SPSS PC 19.0.

VÝSLEDKY: Výsledky faktorové analýzy prokázali strukturu dotazníku o dvou škálách, které byly nazvány „Obecné tvrzení $\mathrm{k}$ integraci ve školní TV“ a „Přesvědčení o vlastním jednání“. Český dotazník prokázal podobnou strukturu s výjimkou počtu tvrzení, které se stali součástí první škály.

ZÁVĚRY: CAIPE-CZ prokazuje vysokou hladinu vnitřní konzistence $(\alpha=0,84)$ a je schopen také rozlišit postoje žáků, kteří mají osobní zkušenosti s dětmi s tělesným postižením a těch kteří takovéto zkušenosti nemají. CAIPE-CZ je tedy vhodný dotazníkem pro budoucí studie zaměřené na postoje dětí $\mathrm{k}$ integraci $v$ tělesné výchově.

Kličová slova: aplikované pohybové aktivity, aplikovaná tělesná výchova, zdravotní postižení, speciální pedagogika.

\section{doc. Mgr. Martin Kudláček, Ph.D.}



Palacký University, Olomouc

Faculty of Physical Culture

tř. Míru 115

77111 Olomouc

Czech Republic

Education and previous work experience

1997 - Palacký University, Olomouc (MSc.).

1998-2000 - graduate teaching assistant at Texas Woman's University, Texas.

2001 - Texas Woman's University (Ph.D.).

Since 2001 - prof. assistant at Palacký University, Olomouc, Czech Republic.

\section{Scientific orientation}

Social-psychological dimensions of disability and sport, recreation and physical education, comparative studies of adapted physical activities, inclusion of people with disabilities through physical education.

\section{First-line publication}

Kudláček, M. (2011). Aplikované pohybové aktivity v evropském kontextu. Tělesná kultura, 34(2), 9-19.

Kudláček, M., \& Barrett, U. (2011). Adapted physical activity as a profession in Europe. European Journal of Adapted Physical Activity, 4(2), 7-16.

Kudláček, M., Kudláček, M., Kudláček, V., \& Kudláček, V. (2010). Components/factors of Czech version of Physical Self Perception Profile PSPP-CZ. Acta Universitatis Palackianae Olomucensis. Gymnica, 40(4), 25-31.

Martin, K., \& Kudláček, M. (2010). Attitudes of preservice teachers in an Australian University towards inlcusion of students with physical disabilities in general physical education programs students with physical disabilities in general physical education programs. European Journal of Adapted Physical Activity, 3(1), 30-48.

Kudláček, M., Dalbesio, I., Janečka, Z., Vanlandewijck, Y., \& Beckman, E. (2009). The analysis of individual skills of ice sledge hockey players at the Torino 2006 paralympic tournament. European Journal of Adapted Physical Activity, 2(2), 39-48.

O’Brien, D., Kudláček, M., \& Howe, P. (2009). A contemporary review of English literature on inclusion of students with disabilities in physical education: A European perspective. European Journal of Adapted Physical Activity, 2(1), 46-61.

Kudláček, M., French, R., Myers, B., Sherrill, C., \& Válková, H. (2002). An inclusion instrument based on planned behavior theory for prospective physical educators. Adapted Physical Activity Quarterly, 19(3), 280-299. 